\title{
Features of using solid cellulose-containing domestic wastes for production of bioethanol
}

\author{
T.A. Bolotnikova ${ }^{1}$, E.B. Aronova ${ }^{1}$, J.G. Bazarnova ${ }^{1}$, O.I. Bolotnikova ${ }^{1,2,}$, A.I. Ginak $^{3}$ \\ ${ }^{1}$ Peter the Great St. Petersburg Polytechnic University, Polytechnicheskaya Str. 29, Saint Petersburg, 195251, Russian Federation \\ ${ }^{2}$ Petrozavodsk State University, Lenina Str. 33, Petrozavodsk, 185910, Republic of Karelia, Russian Federation \\ ${ }^{3}$ Saint-Petersburg State Institute of Technology, Moskovskiy Av. 26, Saint Petersburg, 190013, Russian Federation
}

\begin{abstract}
In this paper, we consider the process of producing biogas with a high methane content when used as a co-substrate for fermentation of plant residues of microalgae. Microalgae Chlorella sorokiniana are a valuable source for obtaining valuable components such as lipids, pigments, proteins, chlorophyll and others. After the extraction of valuable components, residual biomass is formed, which requires further disposal. In this experiment, the digestion process is carried out using an inoculant - lyophilically dried activated sludge from sewage treatment plants in Hamburg in the amount of $450 \mathrm{ml}$ and residual biomass of the microalga Chlorella sorokiniana in the amount of $2.1 \mathrm{~g}$. The studies were carried out in the Anaerobes Test system AMPT-II system. Fermentation produces $205 \mathrm{ml}$ of methane gas.
\end{abstract}

\section{Introduction}

The problem of household wastes disposal is becoming increasingly acute from year to year. Almost half of the volume is waste paper and cardboard. Just one family of four people on the average throws out about $100 \mathrm{~kg}$ of paper and packaging wastes per year. The period of the disintegration in natural conditions is from 3 months to a year [1]. The traditional burning of paper wastes is extremely harmful to the environment [2]. Therefore, the development of efficient recycling technologies for such materials is one of the aims for the state policy of developed countries in the field of ecology and waste management.

Using different microorganisms fermenting Dglucose as the main component of cellulose is the main topic of discussion. Bioethanol is widely used not only in various industries, but also as an additive to boiler fuel for internal combustion engines, which meets modern environmental requirements and has a positive economic effect [1]. Enzymatic hydrolysis of abundant paper and paperboard wastes to glucose-containing substrates has significant cost and requires special technologies [3]. Cheapening of this process can be achieved through the use of mineral acids [4]. Similar methods of cellulose destruction were widely used in the USSR in the hydrolysis industry. It was at that time when soft methods for wood hydrolysis were developed, which made possible to reduce the anthropogenic impact on the environment [5]. However, cellulose hydrolysates obtained in this way are unsuitable for ethanol conversion by bacteria, which metabolic activity depends on $\mathrm{pH}$ level of the medium [5]. At the same time, the special strains of Saccharomyces cerevisiae yeast to utilize acid wood hydrolysates are known [6]. Therefore, the purpose of this work was to optimize the parameters of paper and paperboard wastes acid hydrolysis and to evaluate the ethanol yield from these substrates with the help of the special strain of Sacch. cerevisiae "Omskie".

\section{Methods}

For the experiment, paper and cardboard were taken from the house bin in quantities of $1 \mathrm{~kg}$ of each sample. These samples were dispersed in a hydraulic diluent to a homogeneous pulp with fragments of size: $150-200 \times 4$ $\mathrm{mm}$ (newsprint) and $100 \times 5 \mathrm{~mm}$ (cardboard). The dispersion was carried out at atmospheric pressure and $+95^{\circ} \mathrm{C} . \mathrm{H}_{2} \mathrm{SO}_{4}$ was added to the resulting homogeneous mass to a final concentration of $70 \%$. The mixture was stirred, incubated for 2 hours at $+60-70^{\circ} \mathrm{C}$. A part of the acid fraction was removed and water was added to a final concentration of $\mathrm{H}_{2} \mathrm{SO}_{4}$ of $40 \%$. This solution has been incubated for 2 hours under the previous conditions (hydraulic module of 8.7).

The preparation of glucose-containing substrates obtained by the acid method for ethanol conversion was carried out during sequential neutralization with milk of lime, distillation vacuum $\left(+80^{\circ} \mathrm{C}\right.$, pressure at the top of the column $0.7 \mathrm{MPa}$ ), continuously purged with air for 60 minutes to $\mathrm{pH}=4.8$.

The glucose-containing mixture was cooled down to the temperature of $+25^{\circ} \mathrm{C}$, diluted with water to the final concentration of $\mathrm{H}_{2} \mathrm{SO}_{4}$ of $10 \%$, neutralized with $25 \%$ $\mathrm{NH}_{4} \mathrm{OH}$ to $\mathrm{pH}=6.0$. The neutralized solution was filtered and evaporated by $50 \%$ (Table 1). The concentration of

\footnotetext{
${ }^{*}$ Corresponding author: olga-bolotnikova@rambler.ru
} 
reducing sugars in the bottom product was determined by Fehling's test.

Table 1. Obtaining of the bottom product.

\begin{tabular}{|c|c|}
\hline Characteristics & Stage \\
\hline Atmospheric pressure, $+95^{\circ} \mathrm{C}$ & The dispersion \\
\hline $\begin{array}{c}2 \text { hours, } \mathrm{H}_{2} \mathrm{SO}_{4}(70 \%) ; \\
2 \text { hours, } \mathrm{H}_{2} \mathrm{SO}_{4}(40 \%) .\end{array}$ & Acid hydrolysis \\
\hline Milk of lime & Neutralization \\
\hline $\begin{array}{c}+80^{\circ} \mathrm{C}, \text { pressure at the top of the } \\
\text { column } 0.7 \mathrm{MPa}\end{array}$ & Distillation vacuum \\
\hline 60 minutes to $\mathrm{pH}=4.8$ & Air purge \\
\hline Cooling to a temperature of $+25^{\circ} \mathrm{C}$, & Cooling \\
\hline $\begin{array}{c}\text { To a final concentration of } \mathrm{H}_{2} \mathrm{SO}_{4} \\
\text { of } 10 \%,\end{array}$ & Dilution with water \\
\hline $25 \%$ NH${ }_{4} \mathrm{OH}$ to $\mathrm{pH}=6.0$. & Neutralization \\
\hline Evaporation by $50 \%$ & $\begin{array}{c}\text { Filtration, } \\
\text { evaporation }\end{array}$ \\
\hline
\end{tabular}

The bottom product was cooled $\left(+40^{\circ} \mathrm{C}\right)$, diluted with water to a concentration of reducing substances of 10-13 $\mathrm{g} / \mathrm{l}, \quad$ and $\quad 0.02 \% \quad\left(\mathrm{NH}_{4}\right)_{2} \mathrm{SO}_{4} \quad$ and $\quad 0.01 \%$ $\left(\left(\mathrm{CaH}_{2} \mathrm{PO}_{4}\right)_{2} \times \mathrm{H}_{2} \mathrm{O}+2 \mathrm{CaSO}_{4} \times 2 \mathrm{H}_{2} \mathrm{O}\right)$ were added. This wort was fermented with a batch culture of Sacch yeast. cerevisiae "Omsk" (Collection of industrial microorganisms, VNIIHydrolysis, St. Petersburg). Ethanol fermentation conditions were: $100 \mathrm{ml}$ roundbottom Erlenmeyer flasks with $100 \mathrm{ml}$ of wort on a thermostatic rotary shaker for 24 hours at $+30-32^{\circ} \mathrm{C}$. After 18-24 hours $10 \mathrm{ml}$ of yeast suspension from these flasks were transferred to a $500 \mathrm{ml}$ flasks containing 100 $\mathrm{ml}$ of the wort which were incubated under similar conditions. Yeast biomass was used for anaerobic fermentation in an amount of $10.0 \pm 0.5 \mathrm{~g}$ a.d.m. (absolutely dry matter)/l.

After fermentation the yeast biomass was separated in a laboratory centrifuge in 5-10 minutes at $5000 \mathrm{rpm}$. Fractional distillation of ethanol-containing mash was carried out on a distillation unit with a deflector (200 $\mathrm{mm})$. On epuration column ethanol raw was purified to separate the ether-aldehyde fraction. Ethanol concentration was determined in the distillate obtained after distillation of the test sample by gas chromatography under conditions [7]. The experimental results were statistically processed using Student's test at a significance level of 0.05 with the MS Excel computer program.

\section{Results and Discussion}

Today, cellulose-containing waste is a valuable source of recyclable materials, which are widely used to obtain a number of national economic products [8]. However, household waste paper and paperboard of poor quality usually contain bitumen, wax, paraffin, glue and other impurities, clogging nets and cloth of paper machines, sticking to the surface of the drying cylinders [9]. Such contaminated household waste, unsuitable for reextraction of cellulose, is subjected to acid degradation. Therefore, samples of paper and cardboard from the house garbage container were first subjected to thermomechanical processing (so-called cold method).
This ensured not only their crushing to garbage, but also the dispersion of contaminants to sizes that did not significantly affect the process of acid hydrolysis of cellulose.

It is known that the technological parameters of concentrated and diluted acid hydrolysis of wood differ significantly [10]. The undoubted advantages of the first method are the high efficiency of the breaking the $\beta$ glycosidic bonds and, the mild temperature treatment of plant materials. At the same time, significant amounts of acid, the duration and high consumption of gypsum to neutralize the sugar-containing substrate, prior to its microbiological conversion, reduce the commercial attractiveness of such hydrolysis for the disposal of household cellulose-containing waste [10]. The main advantage of dilute acid hydrolysis is the minimal temporary loss. However, the extreme temperature regime, as well as the impossibility of complete degradation of cellulose macromolecules, cast doubt on the environmental friendliness of this method [11]. Therefore, the destruction of ground samples of waste paper and cardboard to glucose-containing substrates was carried out by the combined method, mixing the elements of concentrated and diluted hydrolysis. By the end of 4 hours of such treatment, the fibrous component of municipal solid waste was $95 \%$ converted into a glucose-containing solution. The combined method greatly simplifies the technological scheme and, is characterized by a sufficiently high efficiency and, lower financial costs achieved by reducing corrosion of equipment and reducing the neutralization of acid hydrolysates. In addition, it allows to reduce the volume of water required for acid hydrolysis, and avoid using significant external pressure as a factor that increases the efficiency of the destruction $\beta$-1,4-glycosidic bonds in cellulose macromolecules. These features well illustrate the environmental safety of the developed method.

It is widely known that yeast, in comparison with bacteria and mycelial fungi, is characterized by greater metabolic activity, acidophilicity and fermentative type of sugar catabolism [12]. Special strains Sacch. cerevisiae have already been constructed in the USSR for the disposal of acid wood hydrolysates and byproducts of hydrolysis plants. These strains are traditionally used as ethanol producers [6].

The choice of the strain of Sacch. cerevisiae "Omskie" as a biocatalyst made it possible to prepare wort for fermentation using traditional industrial methods (neutralization, vacuum rectification, continuous air purging, neutralization and filtration) [13]. Towards the end of 24-hour anaerobic fermentation the concentration of RB in the wort decreased to $2.5 \%$, and the yield of ethanol was $52 \mathrm{ml} / \mathrm{kg}$ (paper waste) and $34 \mathrm{ml} / \mathrm{kg}$ (cardboard waste). Theoretical calculations show that scaling the process discussed above will make possible to obtain up to $150 \mathrm{~L}$ of rectified ethanol per ton of absolutely dry cellulose-containing household waste, which corresponds to the standard for the hydrolysis wood industry [14]. 


\section{Conclusion}

During the experiment, optimal conditions were selected for the conversion of household cellulose-containing garbage into glucose-containing substrates. The fundamental possibility for the utilization of household cellulose-containing garbage to bioethanol was proved. This method greatly simplifies the typical technological process of acid hydrolysis of cellulose, reduces its toxic effect on the environment. The use of a special biocatalyst allows optimization of the financial costs of preparing acidic cellulose hydrolysates for ethanol bioconversion through the use of standard detoxification technology. The well-developed network of pulp and paper mill industry in the Russian Federation will become a good technological potential for processing a variety of household and industrial wastes into a target product of great economic importance.

This work was supported by the grant No 18-44-100001 from Russian Foundation for Basic Research (RFBR).

\section{References}

[1] N. Ferronato, V. Torretta, Int. J. Environ. Res. Public Health, 16, 6 (2019).

[2] N. Ferronato, E.C. Rada, M.A. Gorritty Portillo, L.I. Cioca, M. Ragazzi, V. Torretta, J. Environ Manage, 15 (2019).

[3] G.P. Maitan-Alfenas, E.M. Visser, V.M. Guimarães, Cur. Opin. Food Scien., 1 (2015).

[4] M.V. Kharina, O.N. Grigoreva, Proceedings of Universities, Applied Chemistry and Biotechnology, 20, 13 (2017) (in Russian).

[5] O.I. Bolotnikova, N.P. Mikhailova, J.G. Bazarnova, E.B. Aronova, T.A. Bolotnikova, J.N. Akinina, Proceedings of Universities, Applied Chemistry and Biotechnology, 9, 4 (2019) (in Russian).

[6] V.I. Kudryavcev, Katalog kul'tur mikroorganizmov, podderzhivaemyh v SSSR, M: Nauka, 1981, 244 (In Russian).

[7] O. Bolotnikova, J. Bazarnova, E. Aronova, N. Mikhailova, T. Bolotnikova, Pu J. E3S Web of Conferences, 140, 02008 (2019). DOI: 10.1051/e3sconf/201914002008.

[8] L. Simão1, D. Hotza, F. Raupp-Pereira1, J.A. Labrincha, O.R.K. Montedo, Cerâmica, 64, 371 (2018). DOI: 10.1590/0366-69132018643712414.

[9] M. Yılmaz, T. Gümüşkaya, Europ. J. Accounting Auditing and Finanace Research, 3, 4 (2015).

[10] O.I. Bolotnikova, N.P. Mikhailova, A.I. Ginak, Izvestiya Sankt-Peterburgskogo gosudarstvennogo tekhnologicheskogo instituta (tekhnicheskogo universiteta), 39, 89 (2017) (In Russian).

[11] A. Nancib, N. Diboune, N. Nancib, J. Boudrant, J. Appl. Biotech. Bioeng., 4, 1 (2017). EISSN: 25728466.

[12] C.P. Kurtzman, J.W. Fell, T. Boekhout (eds.), The Yeasts A Taxonomic Study, 5th Edition, Elsevier, Amsterdam, Netherlands, 2354 (2011). DOI: 10.1016/B978-0-444-52149-1.00007-0.
[13]B. Tsegaye, C. Balomajumder, P. Roy, Bulletin of the National Research Centre, 43, 51 (2019).

[14]I.I. Korol'kov, Perkolyacionnyj gidroliz rastitel'nogo syr'ya, M.: Lesnaya prom-t', 271 (1990) (In Russian). 